\title{
A visão de um espectador - Para aprender a olhar a cidade. Só ela?
}

É noite e estamos reunidos diante da porta fechada de um pequeno shopping incrustado numa rua estreita do Bom Retiro - bairro paulistano especializado no comércio de roupas. O grupo tem em comum a dúvida do que irá assistir. $O$ espetáculo vai começar a qualquer momento, mas ainda não começou. Não? Enquanto esperamos o início da peça "Bom Retiro 958 metros" observamos a paisagem noturna da rua adormecida. Nada acontece ali nesse horário. A rua de apenas uma quadra não tem movimento, nem de pessoas nem de automóveis, o que leva o grupo a sair das calçadas e esperar no asfalto. Com indiscrição olhamos as vitrines, que ainda não querem exibir-se.

Nosso olhar vai mudando de foco, para tornar-se propenso a captar sinais, receber informação, fazer relações, perceber sutilezas. Uma peça de teatro vai começar. Vai? Então a anestesia ótica com que andamos na cidade tem de ser desativada e substituída. Mas estamos na cidade, não entramos em um teatro. $O$ teatro é lá mesmo.

A experiência estranhadora começa nesse momento. Somos espectadores de uma apresentação teatral, mas ela não começou. Não? E, na rua, então somos o quê? Apenas cidadãos. Olhando a rua. De outro jeito, pois nosso olhar já não é aquele com que chegamos - pois fomos até lá apenas como espectadores. Nossa relação com a cidade, utilitária e funcional, não nos capacita a parar em uma rua e ficar, olhar, observar, sentir, pensar. Só fazemos isso em viagens, quando estamos fora de São Paulo.

A rua é pública, de todos - logo não é nossa (a cidade dos proprietários-consumidores), é dos que por não terem nada só podem ter o que é público. Por isso o território é estranho e a situação desconfortável. Na rua morta, fora do horário comercial, não há mais ninguém - só nós.

As vitrines das lojas parecem pequenos palcos, com espetáculos comprimidos de bonecos. Cenografias montadas para o espetáculo do dia seguinte. 
A porta se abre e estamos agora nas galerias do shopping. O espetáculo começou. Não tinha começado? As cenas vão caminhando e vamos junto. Há um certo alívio pela arrumação dos papéis. Somos finalmente espectadores, e agora os atores conduzem a narrativa, ouvimos o texto e a peça começa a se corporificar diante de nós. Mas nem tanto. Também somos personagens.

A peça se desenvolve territorialmente. Não se trata da ação teatral localizada no palco na frente de estáticas poltronas dentro de uma segura e escura sala de espetáculos. Aqui somos parte da ação. Não há ilusão. O que é, é. Inclusive o tempo, que é também outro, concreto. Além disso, nessa condição tão diferente da do teatro convencional, o desconforto é provocado pelo fato de que somos vistos tanto quanto os atores.

E percebe-se afinal que o texto está a serviço da encenação. Geralmente é o contrário. A estrutura narrativa está lá, os personagens funcionam nessa estrutura, há diálogos, tudo isso se reconhece. Mas esses elementos estão de pernas para o ar. 0 texto está em outro lugar e somos assim convidados a olhar as coisas a partir de outro lugar também. Mesmo porque já estamos misturados com a peça. É como se o texto fosse tomado pelo território, um ocupou a função do outro.

Uma sequência de cenas nas galerias do shopping nos coloca diante de uma situação muito familiar do desfile de consumidores em ação, escolhendo e cercando suas presas perscrutando produtos em exposição. A situação também pode ser lida às avessas, sendo os consumidores as presas seduzidas pelas vitrines. Atores e espectadores, todos são indistintos personagens-transeuntes circulando diante de lojas.

Há outra condição incômoda naquele lugar - uma parte da cidade foi privatizada. Um longo trecho do arrimo da linha do trem, com a rua e tudo, tornou-se parte do espaço interno do shopping. Tornou-se parte da cidade murada dos proprietários-consumidores.

As ruas onde está o shopping têm aliás, uma curiosa história. Nelas, de 1911 até o final da década de 1940, funcionou uma zona de meretrício. Nas fachadas das casinhas, em cada janela hoje substituídas por vitrines, havia uma prostituta - à época conhecida como polaca - esperando seu cliente. Também vestida para a venda, no lugar da prostituta há agora uma manequim.

A presença na peça de manequins com alma evoca a lenda do Golem - criatura mítica recorrente em muitos textos literários - aqui em uma fusão manequim-prostituta-golem. Além disso, outras fusões são operadas na peça, a das etnias e grupos 
sociais que habitam o Bom Retiro - judeus-coreanos-bolivianos-craqueiros, e a do processo de produção e consumo - mercadoria-entulho.

Em seguida saímos, e estamos na rua de novo. Agora encarnando de vez personagens da peça. Numa peça em que a realidade não é representada, mas apresentada. Essa diferença com o teatro tradicional nos coloca na fronteira entre os dois universos: estamos entre a ficção e o real - apontando nesse momento para a fissura entre o espaço público e o privado. Tem-se a impressão que a peça é permanente, está lá sempre, mesmo quando não formatada para ser apresentada.

A estrutura cenotécnica movimenta-se sem trucagens ocultas, e expõe as soluções engenhosíssimas de som, luz e cenário. A presença tão próxima da equipe técnica caminhando junto leva a participação da plateia no enredo - não somos espectadores, mas personagens - para muito além - não somos apenas personagens, mas participamos da própria construção do espetáculo.

Saímos do Bom Retiro deserto das lojas fechadas para as ruas movimentadas onde há moradia, supermercados e bares. Chegamos então ao prédio dos extintos colégio Sholem Aleichem e Casa do Povo, onde entramos nas ruínas do Teatro TAIB. A parte final da peça desenvolve-se nesse lugar poético onde não se encenam mais peças. A cena final se dá na rua, não podia ser diferente. Saímos do teatro arruinado (que é um tanto a condição em que nos sentimos agora), crentes que a peça já terminou. E deparamos com uma caçamba de entulho onde se dá o último diálogo entre duas manequins descartadas como lixo em meio aos ruídos do trânsito de ônibus e automóveis. Para mim é uma das mais importantes cenas da história do teatro brasileiro. Pouco depois, a plateia - que vive a experiência vertical da vertigem - aplaude o elenco, agora separado de nós porque está no outro lado da movimentada rua Três Rios, recortado pelas brechas dos ônibus que passam. 